\title{
IIFS
}

\section{What is A Public Sector Pension Worth?}

Richard Disney

Carl Emmerson

Gemma Tetlow 


\title{
What is a public sector pension worth?*
}

\author{
by \\ Richard Disney†, Carl Emmerson* and Gemma Tetlow \\ † Institute for Fiscal Studies and University of Nottingham \\ * Institute for Fiscal Studies \\ $\ddagger$ Institute for Fiscal Studies and University College London
}

\begin{abstract}
We measure accruals in defined benefit (DB) pension plans for public and private sector workers in Britain, using typical differences in scheme rules and sector-specific lifetime age-earnings profiles by sex and educational group. We show not just that coverage by DB pension plans is greater in the public sector, but that median pension accruals as a \% of salary are almost $5 \%$ higher among DB-covered public sector workers than covered private sector workers. This is largely driven by earlier normal pension (retirement) ages. For workers of different ages in the two sectors, marginal accruals also vary as a result of differences in earnings profiles across the sectors. The differences in earnings profiles across sectors should induce caution in using calculated coefficients on wages from cross sections of data in order to estimate sectoral wage effects.
\end{abstract}

Key words: $\quad$ Pension plans Public sector Retirement

JEL classification: $\quad$ H55 J32 J63

\footnotetext{
* Acknowledgements: We are grateful to the Economic and Social Research Council for funding this work as part of the project on 'Pension wealth, early retirement and job mobility', reference RES-000-23-1149. We thank James Banks, Paul Johnson, Derek Leslie, David Miner and participants at the conference on "Issues in Public Sector Pay" in London on the $14^{\text {th }}$ September 2007 organised by the Centre for Market and Public Organisation (CMPO) for useful comments. The British Household Panel Survey (BHPS) data used in this paper were collected by the Institute for Social and Economic Research at the University of Essex, funded by the ESRC. The Labour Force Survey (LFS) data are Crown Copyright material, and are used with the permission of the Controller of HMSO and the Queen's Printer for Scotland. Both the BHPS and the LFS data were supplied by the ESRC data archive. Responsibility for interpretation of the data, as well as for any errors, is the authors' alone.
} 


\section{What is a public sector pension worth?}

\section{Introduction: pension coverage in the public and private sectors}

Analyses of workers' remuneration using cross-sectional data in the United Kingdom (UK) and elsewhere have uncovered significant differences in pay levels between the public and private sectors after controlling for observed characteristics. ${ }^{1}$ Whether such differentials persist in the long run when we adjust for the self-selection of job movers and measure worker quality more precisely, however, may be open to question. $^{2}$

One reason why long run pay differentials between sectors could persist in a competitive labour market even after controlling for worker heterogeneity is that jobs in different sectors vary in their pecuniary characteristics other than current pay, as well as in non-pecuniary characteristics. It is hard to believe that pay differentials between the public and private sector can be explained largely by differences in nonpecuniary characteristics, ${ }^{3}$ but there is one well-documented difference between public and private sector jobs in the UK: public sector jobs are much more likely to be covered by employer-provided pension plans ('occupational pensions' in UK parlance).

Many occupations, particularly among white collar workers and in the public sector, are covered by 'defined benefit' (DB) pension plans that offer pensions calculated on number of years of service and a measure of salary usually based on the final year or an average of several final years of service. These pension plans typically also contain provisions for early retirement on a variety of grounds (most notably illhealth) and are, in some cases, only partially funded by employee and employer contributions, particularly in the public sector. Employer-provided DB pension plan coverage is much less extensive in the private sector. Many private sector employers have taken advantage in recent years of the liberalisation of the 'contracting-out' rules

\footnotetext{
${ }^{1}$ Previous studies for the UK include Bell et al (2007), Blackaby, Murphy and O’Leary (1999), Henley and Thomas (2001), Disney and Gosling (1998).

${ }^{2}$ See, for example, Disney and Gosling (2003), Nickell and Quintini (2002), and Postel-Vinay and Turon (2005).

3 With the UK public sector increasingly dominated by white collar occupations in public administration, health and education, given the privatisation and contracting-out of many manualdominated previously-public sector activities in the 1980s and 1990s, evidence of positive pay premia for public sector workers is hard to explain by non-pecuniary factors (except in rather obvious subsectors such as the armed forces). However the findings of Di Nardo and Pischke (1997) can be taken as evidence that there is a pay premium attached to white collar occupations in general.
} 
in the late-1980s to shift towards 'defined contribution' (DC) pension plans in which the employee, at least formally, bears all of both the investment risk during the accumulation phase and the annuity rate risk at the initial point of withdrawal. In this paper, we focus exclusively on differences in DB pension coverage between the public and private sector, and calculate what DB pension coverage is 'worth' to workers in the two sectors using new household data.

Figure 1 illustrates the UK's trends in public and private sector membership by DB pension plans over the period $1978-79$ to $2003-04$, using official data. ${ }^{4}$ It shows that DB membership steadily declined in the private sector throughout most of the period whilst rising slightly in the public sector. These figures however understate the disparate underlying trends in coverage, especially in the late 1980s, because several industries such as utility providers were privatised during this period and such industries tended to have levels of DB pension coverage that were, on average, higher than those in the rest of the private sector. ${ }^{5}$

$$
<<\text { Figure } 1 \text { here }>>
$$

The disparate trends would be better illustrated by trends in coverage rather than total membership - unfortunately it is hard to obtain consistent public and private sector employment figures to match exactly to these official data. ${ }^{6}$

To gain an idea of recent differences in public-private sector coverage by DB plans, Table 1 uses data from the British Household Panel Survey (BHPS) for 2001, which asks respondents about the nature of their pension plan coverage (i.e. DB or DC) and their sectoral affiliation. The table differentiates DB coverage rates by sex, by two age bands, by social class and by 'low', 'medium' and 'high' education defined respectively as leaving school at first school leaving age, staying in full-time education until 18, or leaving full-time education after age 18. The table shows a clear

\footnotetext{
${ }^{4}$ 'Contracted-out' in the Figure refers to the arrangement over the period whereby, in the case of members of DB pension plans, employees and employers can pay a lower rate of social security contribution in return for the employee relinquishing rights during their contracted-out period to the second-tier social security pension scheme. The vast majority of DB plans will have chosen to contractout over this period. Note also that this source of data does not therefore provide exhaustive details on coverage by DC pension plans (either employer or individual based) - some of these will also have been contracted-out while others will have been contracted-in.

${ }^{5}$ See pages 114 to 117 of Pensions Commission (2004) for details on pension coverage over time taking into account the impact of privatisation.

${ }^{6}$ There are data for public and private sector employment - for example from the Labour Force Survey or NES/ASHE but it is difficult to get these figures to aggregate to the totals which match the DWP data in Figure 1. Broadly, private sector employment was falling in the 1990s and public sector employment rising after 2000 .
} 
disparity in coverage for both sexes, by age group and by education, across sectors. Men and those with more education are more likely to be covered by DB pension plans in both the public and private sectors. Note that the probability of coverage tends to rise with age for all workers in the private sector and for men in the public sector; less so for women in the public sector.

$$
<<\text { Table } 1 \text { here }>>
$$

The observed average characteristics of private sector DB members also differ considerably from those of public sector DB members. As shown in Table 2, on average those who are members of private sector arrangements are much more likely to be men and, on average, less likely to be in Social Class group I or II (professional or intermediate), to have lower levels of education and to be slightly younger than those who are members of public sector pension arrangements. Amongst men, members of private sector DB pension schemes have significantly higher mean earnings than members of public sector DB pension schemes, while amongst women there is no statistically significant difference in mean earnings between those who are members of private sector DB schemes and those who are members of public sector DB schemes. ${ }^{7}$

$<<$ Table 2 here $>>$

To the extent that DB pension arrangements are more generous than DC arrangements, the disparity in employer-provided pension coverage across sectors will provide a significant pecuniary advantage to many in the public sector. This might compensate for any pay 'penalty' or augment any measured pay 'premium' to public sector occupations. Moreover, apart from this remuneration 'levels' effect, there is also a 'differences' effect. Whilst the value of being covered by a public sector pension plan has declined somewhat in recent years due to a tightening of early retirement eligibility and efforts to increase employee contributions as a share of the total cost of providing pensions, the value of private sector pension coverage may have deteriorated more quickly due to the shift from DB to DC arrangements where that shift is associated with a drop in the size of the employer's contribution. This point concerning the evolution of relative pension generosity over time has sometimes been made by pay negotiators on behalf of government departments in arguing that

\footnotetext{
${ }^{7}$ These two statements are true both unconditionally and conditional on age.
} 
public sector pay scale 'uplifts' should be below those negotiated in the private sector. $^{8}$

We have recently calculated accrued and prospective pension rights for workers from all sources (including state-provided contributory benefits, employerprovided pensions - both DB and DC - and personal pension accounts) using detailed evidence from the BHPS in 2001 (see Disney, Emmerson, Tetlow and Wakefield, 2007a and 2007b for further details). Such calculations give pension rights that vary by characteristics (notably by age, education, sex and various provisions of the pension plan) and also depend on which of several plausible methods of measuring pension entitlements is chosen. In this analysis, we focus on these valuations of pension rights for members of employer-provided DB plans, distinguishing between public and private sector workers. Covered workers in the two sectors are found to have different accrued and prospective rights as a result of differences in average pension tenure, normal pension age, earnings profiles and accrual factors. Coverage differences may be an important source of variation in pension rights across the two sectors but are certainly not the whole story. ${ }^{9}$

However, before considering these calculations, it is useful to consider briefly the basic economics of the relation between pay and pensions, and in particular the standard neo-classical model in which different components of the pay package might be substitutes, and pensions in particular are seen as a form of compensatory arrangement.

\section{Pensions and wages: theory and evidence}

The basic theory of pecuniary and non-pecuniary compensation for pay differences needs little elaboration. Drawing on the standard model of the determination of remuneration levels across workers in a competitive market, a natural hypothesis is that, for a worker of given characteristics doing a job with

\footnotetext{
${ }^{8}$ For example, the UK Health Departments, in their 2007 evidence to the NHS Review Body, which recommends pay uplifts to all workers covered by the NHS pay structure, noted that: "NHS pensions were a very valuable benefit which [the Review Body] might wish to take into account in assessing pay levels needed for recruitment and retention” (NOHPRB, 2007, para \# 7.17).

${ }^{9}$ We reiterate that we are comparing the coverage and generosity of DB plans across sectors and do not examine the implications of the switch from DC to DB plans in the private sector. Such an analysis raises a number of additional issues concerning the intrinsic characteristics of the two types of pension plan as well as consideration of accumulated wealth in both DB and DC pensions - see Disney and Whitehouse (1996) and Disney et al (2007a).
} 
certain characteristics, differences in future remuneration (e.g. pension rights) should offset differences in current wages. In principle, a test could easily be applied to measure an 'offset' coefficient in practice. Such a test could be carried out on pay levels, or by some methodology in differences that measured how, as pay evolved over time, the value of pension entitlements varied to compensate for differential changes in pay.

There is some econometric evidence from the United States which supports such an 'offset' between current pay and future pension rights (as in Schiller and Weiss, 1980 and Woodbury, 1983) but such empirical results are most convincing only when studies utilise data where a single employee is offered alternative 'packages' of current and deferred remuneration (as in the Woodbury paper). A wellpublicised illustration of this trade-off in remuneration packages was the UK Financial Services Authority's decision in 2003 to offer higher wages to those who opted not to join the employer-provided DB plan than to those that had. However few studies based on cross-sections of employees' wages and pension plan coverage find convincing evidence of remuneration trade-offs of this type - indeed the correlation of pension rights (often imperfectly measured) and current pay is typically positive in such regressions and not negative as a naïve model of pecuniary compensation might suggest.

One simple reason for failing to find offsets is that prospective pension rights are not measured correctly - a deficiency that we attempt to rectify here. A second limitation of such studies, which stems from their failure to consider the seminal work of Lazear (1979, 1981), is noted, inter alia, by Disney and Whitehouse (1996) and Ippolito (1997). If employers 'tilt' remuneration towards later in the working life as an incentive device, both in the form of pension rights and 'wage tilt', cross-section regressions of wages at a point in time on prospective pension rights are unlikely to provide a robust test of the hypothesis, even with basic controls such as seniority. Suppose for example, that private sector age-earnings profiles are largely characterised by the standard 'inverted $U$ ' associated with the accumulation and depreciation of human capital, whereas, for whatever reason, public sector profiles are characterised by incremental ('seniority-based') pay structures. A simple pooled cross-section regression which imposes the same coefficients on age across both profiles will likely fail to find any (negative) correlation between current (as opposed 
to lifetime) pay and current accrual of pension rights. Moreover, workers with identical total lifetime remuneration but different age-earnings profiles can accrue different pension rights at retirement in DB pension schemes that are not based on average earnings.

We utilise data from the Labour Force Survey (LFS) to investigate whether there are systematic differences in age-earnings profiles between the public and private sectors (and use these profiles in the next section to construct prospective pension accruals). These profiles are constructed by pooling thirteen years of the LFS from 1994 to 2006 (inclusive), netting out the average annual growth of earnings in the public or the private sector as applicable, and running quantile (median) regressions of reported (log) gross annual earnings on (five year moving average) age dummies separately for public and private sector workers of each sex and education group. The profiles are not therefore 'true' longitudinal profiles, although they can be so regarded if we discount future earnings at the average rate of earnings growth. The specification using five year moving average age dummies is depicted in Figure 2 (for men, A, and women, B). In other calculations (for example where we need to project pension rights), we find that these age-earnings profiles can be approximated by quadratics in age for men at least, albeit again we then allow for different curvatures according to sex, education and sectoral affiliation.

$$
<<\text { Figure } 2 \text { here }>>
$$

Figure 2A illustrates the age-earnings profiles for men by educational group and sectoral affiliation. Cumulating these data, the total lifetime remuneration in absolute terms of a man working throughout from age 21 to 59 in the public sector relative to the private sector is 3.3\% higher for the lowest educational group, 5.7\% higher for the middle educational group and $4.9 \%$ lower for the highest educational group. ${ }^{10}$ These differences are statistically significant. ${ }^{11}$

\footnotetext{
${ }^{10}$ Note that we have netted out average earnings growth in each sector to focus on the age-earnings profile. Systematic differences in trend growth between the two sectors over any long period will therefore qualify this conclusion. In fact, over this period (1994-2006) earnings rose 0.4 percentage points faster per annum in the private sector than the public, but a later (or indeed earlier) starting date would give a somewhat different result.

${ }^{11}$ We carry out an F-test on whether or not the sum of the co-efficients in the log earnings equation are statistically different between men in the public sector and men in the private sector for each of these education groups. The test statistics $(\mathrm{F}(1,189721))$ for the lowest, middle and highest education groups are $9.27,18.27$ and 20.88 all of which are statistically significantly different from zero at the $1 \%$ level.
} 
Noticeable features of Figure 2A are that there is little difference in the ageearnings profiles across the public and private sector for men in the lowest educational group, less evidence of declining wages for older public sector workers in the middle educational group relative to the private sector, and a marked greater 'hump' (curvature) to private sector workers lifetime pay in the highest educational group - for example at age 40, private sector degree-educated workers are on average earning over 18\% more than their public sector counterparts (with the estimated difference in median log wages being statistically significant at the $1 \%$ level $\mathrm{F}(1,189721)=7.48)$ even though the lifetime differential is only $4.9 \%$. There are also differences in age-to-age volatility though this may just be sampling error.

Figure 2B illustrates the profiles for women. These are very different between sectors, and it is important to note that this in part stems from our use of weekly not hourly earnings. So they are in part driven by changes in hours of work over the life cycle as well as variation in hours across sectors. Overall, women in the public sector throughout their working life have cumulatively higher total earnings than in the private sector: respectively $12.9 \%$ for the lowest educational group, $20.1 \%$ for the middle and $36.1 \%$ for degree level. Again these differences are statistically different from zero (with the F-test statistics, $F(1,189721)$, for the lowest, middle and highest education groups being 176.24, 391.86 and 735.94 respectively). This likely arises from a combination of both differences in hours and pay. Whilst there seems to be a positive differential at most ages to the public sector, the impact is strongest among workers after age 40 and especially among the most educated workers. We attribute this difference to women disproportionately continuing in career jobs in the public sector (such as public administration, education and health) whereas private sector women with the same qualifications are more prone to cut their hours. ${ }^{12}$ Given this variation in hours, the underlying curvatures of age-earnings profiles facing women who remain in full-time work through most or all of their working life are perhaps better represented by the profiles for men.

Since most analyses of private and public sector earnings focus on 'snapshots' of earnings at particular ages, these lifetime profiles are of intrinsic interest. However

\footnotetext{
${ }^{12}$ An alternative explanation would be higher earning women in the private sector being more likely to leave the labour market once they have children than higher earning women in the public sector.
} 
their main use in the current context is to underpin calculations of pension rights across sectors, to which we turn in the next section.

\section{Pension rights}

Knowledge of several variables in addition to earnings profiles are required in order to provide a quantitative estimate of the value to each covered worker of membership of an employer-provided DB pension plan. These include:

- $\quad$ The worker's tenure (years of service) in the pension plan;

- $\quad$ The timing of that pension tenure relative to retirement;

- $\quad$ The first age in the pension plan at which the member can normally collect benefits ('normal pension age'); ${ }^{13}$

- $\quad$ The accrual factor as a fraction of salary and other design features of the programme such as integration of the plan with the state scheme and any ceilings or floors to eligible earnings;

- Whether or not at the time of their death the plan member has a living husband, wife or civil partner who will continue to receive a stream of pension income;

- Vesting rules - that is, how long the worker has to be in the job to be eligible for pension benefits;

- $\quad$ The time profile of pay;

- $\quad$ Any differences in the scope for early retirement e.g. on grounds of illhealth (which we do not consider here).

In general terms, assume that the pension plan pays a capitalised annuity stream or pension benefit $(P B)$ from a known age, $R$, that depends on years of service $(n)$, a measure of the wage, $W$, and an accrual rate as a fraction of salary times an annuity factor related to life expectancy when the pension is first drawn $(\beta)$. The present value of the accrued pension rights of an individual at working age $a$ can be written as:

$$
P V(P B)_{a}=\beta n W_{a} e^{-r(R-a)}
$$

\footnotetext{
${ }^{13}$ Usually termed 'normal retirement age' in pension plans although individuals may in fact not retire from the workforce at this date. Note that 'normal pension age' is plan-specific and should not be confused with the 'state pension age' at which people can first collect the state pension.
} 
where the appropriate wage in determining pension benefits is the most recent (current) wage and the stream is discounted at rate $r$. To compute the one period accrual from being in the plan for another year, we take the expected change in wages which is described below. The one year accrual can then be written as:

$$
P V(\Delta P B)_{a \rightarrow a+1}=(n+1) \beta \hat{W}_{a+1} e^{-r(R-a)}-n \beta W_{a} e^{-r(R-a)}
$$

For individuals who are currently married we also take into account the value of survivor benefits. ${ }^{14}$ We now briefly describe the variables that underlie our estimates of (1) and (2).

\section{Job tenure}

Job tenure primarily affects accrued rights to pensions although in general it is the prospective rights from continuing in the pensioned job that are a key component of the 'option value' method of viewing remuneration in the job (Stock and Wise, 1990; Ippolito, 1995). ${ }^{15}$ However current tenure in the pension plan can also affect prospective rights insofar as a growth in wages would increase pension entitlements even if pension tenure were not increased (see equation 2).

In what follows we focus on the value of prospective one-year accruals of pension rights as the natural number to benchmark on annual pay, and for which accrued pension tenure is not a key determinant. Even so, in the context of accrued pension rights, it is interesting to note that median (mean) uncompleted pension plan tenures are considerably higher in the public sector than the private sector, at 10.5 (12.2) years compared to 6.5 (9.5) years, among covered workers. (We use the selfreported date of first joining the plan in the pension module of the BHPS in 2001 to calculate current pension plan tenure.) These differences are statistically significant. This difference is likely to have arisen because public sector workers typically have longer job tenures than private sector workers ${ }^{16}$ and also because public sector DB pensions are generally more portable across public sector jobs than private sector DB plans, as the latter tend to be employer-specific. Differences in pension tenures are an important factor in explaining why we calculate median (mean) accrued current DB

\footnotetext{
${ }^{14}$ These are set at $50 \%$ of the pension.

${ }^{15}$ For example, in a pure 'option value' model it is the prospective accrual in each future period that governs continued membership of the pension plan. However in more general models of state transitions e.g. retirement, accrued wealth may have an impact on saving, and therefore on labour market transitions.

${ }^{16}$ See Macaulay (2003)
} 
pension rights in our sample among public sector workers to be $£ 36,005(£ 69,257)$ compared to $£ 24,462(£ 49,534)$ for private sector workers.

\section{Retirement (pension) age}

A key determinant of prospective pension rights is the age at which the worker can first receive full pension benefits without suffering a reduction in benefits on the grounds of early retirement (typically $4 \%$ per annum in UK pension plans). In our calculations, we assume that public sector workers have a normal pension age of 60 and private sector workers have a normal pension age of 65 . A lower normal pension age of course increases the value of prospective pension rights up until that age. The bases for choosing these normal pension ages are evidence reported in Bacon and Woodrow's annual Pensions Pocket Book stating that two thirds of members of DB plans surveyed by the National Association of Pension Funds (NAPF) in the private sector report a normal pension age of 65, whereas a majority of public sector workers are covered by plans that report a normal pension age of 60. Among the minority of public sector workers reporting a normal pension age of 65, however, are members of the Local Government Pension Scheme which, whilst having a 'normal pension age' of 65, also applied the 'rule of 85'. Under this arrangement, which has since been reformed, individuals who retire before 65 qualified for unreduced pension benefits if their combined age and years of tenure in the pension plan reached 85 (although drawing pension benefits before age 60 required the permission of the employer). ${ }^{17}$ This rule means, of course, that a worker with as little as 25 years of pension tenure could retire on an unreduced pension at age 60 (and in some cases earlier).

Since we are examining workers who have not yet retired, we do not know the actual retirement age of workers and, to the extent that expected retirement ages (or, more strictly, ages at which workers expect first to receive their pension) differ from these normal pension ages, we are incurring potential measurement error by mechanically applying rules governing normal pension age. However, data from the English Longitudinal Survey of Ageing ${ }^{18}$ show that in 2002-03, among DB-covered workers aged between 50 and 59, there is a correlation between reported normal pension age and expected date of retirement: workers who report a normal pension

\footnotetext{
${ }^{17}$ Source: http://www.lgps.org.uk/

${ }^{18}$ Marmot, M. et al. (2005). These data were supplied by the ESRC data archive.
} 
age of 65 are significantly more likely to expect to work beyond 60 than those who report a lower value of their normal pension age.

\section{Accrual factors and vesting rules}

NAPF data show that the 'typical' private sector DB plan (i.e. $70 \%+$ of covered members) applies a $1 / 60^{\text {th }}$ accrual rate to each year's service whereas a typical public sector DB plan (around two-thirds of covered members) applies a $1 / 80^{\text {th }}$ accrual rate and offers a lump sum equal to $3 / 80^{\text {th }}$ of plan value at pension age. Since these features offset, in terms of generosity, they are not as important a determinant of sectoral differences in pension rights as, say, differences in normal pension ages. There are other potential differences: for example, in whether plans are integrated with either the contribution limits or benefits paid by the state (social security) programme. ${ }^{19}$ Vesting rules - that is, the period of membership before members first become entitled to pension benefits - are typically two years compared to the United States, where such periods can be 5-10 years. In fact the costs to members of vesting periods have also been reduced still further in the UK since, under the 2004 Pensions Act, members have the right to receive a transfer value from the scheme based on a valuation of their own contributions, employer contributions and investment return if they leave before two years whereas previously they were only entitled to a refund of employee contributions. In our calculations, we focus only on accrual rates and accordingly apply the different accrual formulae to public and private sector workers.

\section{Life expectancy}

Accrued rights, and future accrual, will both be higher for individuals with longer life expectancies which, among other things, vary by both sex and social class. For example over the period 1997 to 2001 women in Social Class group I (professional) aged 65 had a remaining life expectancy of 20.6 years compared to just 13.3 years among men in Social Class group V (unskilled manual) (Donkin, et al, 2002). In our calculations we use cohort life expectancies which vary by both age and sex, and make an adjustment for differences in life expectancy by social class. ${ }^{20}$

\footnotetext{
${ }^{19}$ Evidence from the Pensions Pocket Book suggests that private sector plans are more likely to integrate with state benefits than those in the public sector. There are different methods of integration (on benefits, contribution schedules etc) but, to the extent that integration means lower benefits for given contributions, plans that are not integrated are more generous.

20 Cohort life expectancy by age and sex is taken from the latest (2004) UK projections from the Government Actuary’s Department (http://www.gad.gov.uk/). We assume that the percentage
} 
Differences in life expectancy between public and private sector pension arrangements in our model therefore arise insofar as the composition of members by sex, age and social class differ (see Table 2).

\section{Employee contributions}

The expected generosity of accrued and prospective pension rights to an employee will also depend on the extent to which the rights are being covered by his or her own pension contributions. However, at least in 2000, NAPF data show that on notional average employee contributions to final salary pension schemes were slightly higher in the private sector than in the public sector (4.6\% of salary compared to $3.9 \%$ of salary). The distribution of employee contributions in the public sector is twopeaked: public sector plans are more likely to have relatively high employee contributions rates (of between $5 \%$ and $6 \%$ of salary) but they are also more likely to have relatively low employee contributions rates (of $2 \%$ of salary or less). However the measure of salary that we use in our analysis is inclusive of pension contributions, so we implicitly assume that the employee's contribution rate is the same in the public and private sector. ${ }^{21}$

\section{Earnings profiles}

As we are interested in the relation between pensions and pay, a natural measure of pensions is the prospective accrual of additional pension rights arising from one more year's tenure in the pension plan as a fraction of annual pay. To estimate these accruals, we utilise the LFS-based age-earnings profiles constructed as described in Section 2, as well as the accrual factors and assumption as to normal pension age described above. Since we are forecasting prospective earnings, we replace the smoothed age dummies derived from past data used in Figure 2 by a quadratic in age, which (for men at least) provides a good approximation to the underlying curvature (see Figure 2A). Since the profiles are calculated net of

difference in life expectancy by social class (separately for men and women) existing in England and Wales over the period from 1997 to 2001 continues in the future. Where social class is not known we use that of the individual's partner, father or mother (in that order). In the 13 cases (out of a total of 2,134 ) where the social class of a member of a final salary pension arrangement is still not known we assume that high education individuals are in Social Class I, mid education individuals are in Social Class IIIN and that low education individuals are in Social Class V.

${ }^{21}$ The incidence of employer's contributions and the distinction between fully-funded, partially-funded and unfunded pension plans raises further issues which we do not consider here, since our primary focus is on valuing deferred pay (pension rights) relative to current pay. 
economy-wide earnings growth in the public and private sector we add in an additional 2\% per annum to reflect common economy-wide trends across sectors. Furthermore we restrict the profiles so that no individual sees a real decline in their pay of more than $2 \frac{1}{2} \%$ on the basis that this would represent a nominal cut in salary (assuming inflation of $2 \frac{1}{2} \%$ ) which might be deemed unlikely. Given that women's age-earnings profiles are affected by both pay rates and hours (see Figure 2B), we apply men's incremental age-earnings profiles to both men and women when calculating prospective accruals of pension rights over the next period. ${ }^{22}$ The increment in pension wealth (accrual) is then measured as the value of pension rights after one more year's membership of the plan less the value of current pension rights as in equation 2.

Table 3 provides the absolute median values of these prospective one period pension accruals for the BHPS sample as a whole and for various sub-categories. The table also provides calculations of these accruals as a fraction of annual earnings and both the absolute and percentage of salary differences in these accruals between the public and private sector for each type of worker. Overall, average public sector pension accruals are found to be $24.8 \%$ of salary compared to $20.1 \%$ of salary for private sector workers. The somewhat greater life expectancy of women at the same pension age means that their accruals are somewhat higher as a share of earnings. However in absolute terms they are lower which is due to women's average wages being lower than those of men. Looking at differences in pension accrual as a share of earnings by sex and social class we find this ranges from $26.3 \%$ among women in the public sector in Social Class group II (intermediate, which, for example, includes teachers) to $16.9 \%$ among men in the private sector in Social Class group IV (semiskilled manual).

\section{$<<$ Table 3 here $>>$}

Overall, pension absolute accruals in the public sector are almost 20\% higher than in the private sector, but this discrepancy stems wholly from the highest educated

\footnotetext{
${ }^{22}$ This may seem an extreme assumption, but not if it is believed that differential changes in men and women's pay changes arise largely from differences in age, sector or education (for which we control). In relation to different average labour market experience between men and women, different pay levels arising from differential experience between men and women do not matter for our calculation; however if experience affects the growth of pay, our method is a simplification - for example if experience affects promotion prospects. Note that the implementation of job evaluation-based pay modernisation in the public sector in recent years should limit the scope for discriminatory pay increases between men and women based, directly or indirectly, on grounds of sex.
} 
group for both sexes and from men who left school at 18 (the middle educated group). As a share of earnings we find that one-period pension accruals are higher in the public sector than in the private sector by a slightly larger amount for both men and women with higher levels of education, and men who left school at age 18, than it is for women who left school at age 18 and for both men and women who left school at 16. The greater one-period pension accruals in public sector DB arrangements for men with higher levels of education will go some way to mitigating the greater pay seen in the private sector for this group (see Figure 2A).

Figure 3 illustrates the cumulative distribution function (cdf) of one period pension as a fraction of current pay, differentiated by sector. Note that a few accruals are negative because the curvature of the age-earnings profile outweighs the assumed $2 \%$ economy-wide earnings growth so that some individual workers have simulated negative real incremental earnings growth. Overall, however, it can be seen clearly that the public sector cdf lies to the right of the private sector cdf, confirming the summary statistics reported in Table 3.

$<<$ Figure 3 here $>>$

\section{Interpretation and conclusion}

The analysis in the preceding section has confirmed not just that public sector workers are more likely to be covered by DB plans than private sector workers but also that as a percentage of salary the incremental accruals of pension wealth for DB covered public sector workers on average exceed those for $D B$ covered private sector workers. For most groups, but not all, accruals in public sector DB arrangements are also worth more in absolute terms than those in private sector DB arrangements. For men with higher levels of education, the additional pension increments of public sector workers offset the somewhat lower values of cumulated lifetime earnings for public relative to private sector workers that are covered by DB plans (assuming workers stay in the same sector throughout their life and on average follow the median profile for their educational group). For men who left education earlier there is no clear compensatory relationship. For women, we observe very different trajectories of earnings for women in the public sector relative to the private sector, 
especially among those with higher levels of education. We interpret these as largely associated with differences in hours arising from different career trajectories and the nature of private and public sector jobs for women.

Overall, however, the results emphasise two points made in the introduction. First, comparisons of public and private sector pay which ignore differential pension accruals miss an important part of the 'story'. One-period accruals in the public sector are, on average, worth $4.7 \%$ of salary more in a public sector DB scheme than in a private sector DB scheme. Second, that attempts to test models of pecuniary compensation or pay differentials based on cross-section regressions pooled across sectors and with common parameters (especially with respect to age) are likely to generate erroneous results.

We have shown that, on average, pension accruals are more generous for those covered by DB plans in the public sector than those covered by DB plans in the private sector. This could be for two reasons: first the effect of the different pay trajectories illustrated in Figure 2 (since pensions ultimately depend on salary at the end of the tenure in the pension plan) and second, the result of different plan rules between the two sectors: accrual factors, normal pension ages etc. We undertake a simple decomposition to discover whether it is the different age-earnings profiles in the sectors or whether it is the different plan rules (and primarily differences in normal pension ages) that cause the discrepancy in pension accruals between the two sectors.

Table 4 undertakes this decomposition exercise for all public sector workers; it also differentiates the results by whether they are aged less than 40, or 40 and over. The first panel analyses all public sector workers, taking the average public sector accrual and then sequentially adjusts it by first replacing the public sector plan rules by those for the private sector, and then substituting private for public sector ageearnings profiles. Overall these two changes would reduce the one-period pension accrual. The analysis shows that just under two thirds of this reduction arises from different plan rules with the remainder from the different earnings profiles. Were the public sector rules to be replaced by private sector rules (with sector-specific earnings profiles), average absolute accruals would be similar in the two sectors (£3,638 in the public sector from Table 4 and £3,562 in the private sector from Table 3), but additionally replacing the public by private earnings profiles would reduce the 
average absolute accrual among workers in the public sector below that in the private sector. (This is because a greater fraction of public sector workers are aged over 40 , as indicated by the difference in average ages of members of each type of scheme in Table 2, and the ensuing discussion there applies). If the policy objective is to equalise absolute pension plan accruals in the two sectors, therefore, it would seem that changing the plan rules (and, primarily, the difference in normal pension age between the typical public and private sector plan) is a more sensible policy instrument than altering the wage structure.

$<<$ Table 4 here $>>$

Table 4 also illustrates how this finding would differ if we look at workers aged below 40 and those aged 40 and over (since younger workers in the private sector will typically now have access only to DC plans, this is a particularly important issue). For younger workers, public pension accruals are in general a higher fraction of pay than for older workers; this would be reduced substantially by giving such workers the private sector plan rules. However imposing private sector earnings profiles on public sector workers would raise average pension accruals among young workers: this is not surprising given the different age-earnings profiles illustrated in Figure 2 - especially for those with higher levels of education. Conversely, for older workers, a change to private sector earnings profiles for public sector workers would reduce pension accruals even more sharply. Subject to sample size limitations, it is of course possible to undertake different decompositions and sub-analyses but these results illustrate the broad picture.

What are the policy implications of the analysis? First, the results suggest that treating public sector pensions as a 'free lunch' for all public sector workers can be misleading: there is some evidence of compensation (offset) for comparisons across sectors for men with higher levels of education, and for women the career trajectories are so different in the two sectors that any pay-pension comparisons should be treated with caution. Of course other factors, which we have not considered, such as the extent of early retirement provisions and the amount of job security, may also differ between the public and the private sector. A further key policy issue is the extent to which the shift from DB to DC arrangements in the private sector, and any associated reduction in employer contributions, has led to headline differences in pay growth between the public and the private sector understating differences in total 
remuneration. Analysis of this issue, given that further waves of household panel data containing the relevant information are now becoming available, is a priority for future research.

\section{References}

Bell, D., Elliott, R., Ma, A., Scott, A. and Roberts, E. (2007) 'The pattern and evolution of geographical wage differentials in the public and private sectors in Great Britain', Manchester School, 75, July, 386-421.

Blackaby, D., Murphy, P. and O’Leary, N. (1999) 'The payment of public sector workers in the UK: Reconciliation with North American findings', Economics Letters, 65, 239243.

DiNardo, J. and Pischke, J-S. (1997) 'The returns to computer use revisited: Have pencils changed the wage structure too?' Quarterly Journal of Economics, 112, February, 291-303.

Disney, R., Emmerson, C., Tetlow, G. and Wakefield, M. (2007a) 'Accrued and prospective pension rights in Britain', Report on ESRC grant RES-000-23-1149. mimeo, Institute for Fiscal Studies, London.

Disney, R., Emmerson, C., Tetlow, G. and Wakefield, M. (2007b) Pension Wealth in the British Household Panel Survey: User Guide, submitted to ESRC Data Archive with data under ESRC grant RES-000-23-1149.

Disney, R. and Gosling, A. (1998) 'Does it pay to work in the public sector?' Fiscal Studies, 19, November, 347-374.

Disney, R. and Gosling, A. (2003) 'A new method for estimating public sector pay premia: Evidence from Britain in the 1990s', CEPR Discussion Paper 3787, London.

Disney, R. and Whitehouse, E. (1996) 'What are occupational pension plan entitlements worth in Britain?' Economica, 63, May, 213-238.

Donkin, A., Goldblatt, P. and Lynch, K. (2002) 'Inequalities in life expectancy by social class, 1972-1999’, Health Statistics Quarterly, 15, Autumn, 5-14, updated to 2001.

Henley, A. and Thomas, D. (2001) 'Public sector employment and the public-private wage differential in British regions', Regional Studies, 35, 3, 229-240.

Ippolito, R. (1995) 'The labor contract and true economic pension liabilities', American Economic Review, 75, 5, 1031-1043.

Ippolito, R. (1997) Pensions Plans and Employee Performance: Evidence, Analysis and Policy, Chicago University Press.

Lazear, E. (1979) 'Why is there mandatory retirement?' Journal of Political Economy, 87, December, 1261-1284.

Lazear, E. (1981) 'Agency, earnings profiles, productivity and hours restrictions', American Economic Review, 71, 606-620.

Macaulay, C. (2003), 'Job mobility and job tenure in the UK', National Statistics feature, http://www.statistics.gov.uk/articles/labour_market_trends/jobmobility_nov03.pdf

Marmot, M. et al. (2005), English Longitudinal Study of Ageing (ELSA): Wave 1, 2002-2003 [computer file], 2nd edition, Colchester, Essex: UK Data Archive [distributor], June 2005. SN: 5050. 
Nickell, S. and Quintini, C. (2002) 'The consequences of the decline in public sector pay in Britain: A little bit of evidence', Economic Journal, 112, February, F107-F118.

NOHPRB (2007) Review Body for Nurses and Other Health Professions: Twenty-Second Report, Cm 7029, The Stationery Office: London.

Pensions Commission (2004), Pensions Commission (2004), Pensions: Challenges and Choices. The First Report of the Pensions Commission, London: The Stationery Office.

Postel-Vinay, F. and Turn, H. (2005) 'The public pay gap in Britain: small differences that (don’t) matter?', CEPR Discussion Paper 5296, London.

Schiller, B. and Weiss, R. (1980) 'Pensions and wages: A test for equalising differences', Review of Economics and Statistics, 62, 463-468.

Stock, J. and Wise, D. (1990) 'Pensions, the option value of work and retirement', Econometrica, vol. 58, no. 5, pp. 1151-1180.

Woodbury, S. (1983) 'Substitution between wage and nonwage benefits', American Economic Review, 73, 166-182. 
Table 1

DB pension coverage by age, sector, sex, education level and social class group

\begin{tabular}{|c|c|c|c|c|c|c|c|c|c|}
\hline & \multicolumn{9}{|c|}{$\%$ covered } \\
\hline & \multicolumn{3}{|c|}{ Age 20-39 } & \multicolumn{3}{|c|}{ Age 40-59 } & \multicolumn{3}{|c|}{ All 20-59 } \\
\hline & Public & Private & All & Public & Private & All & Public & Private & All \\
\hline All & 69.8 & 26.7 & 36.9 & 70.0 & 33.2 & 45.7 & 69.9 & 29.4 & 40.9 \\
\hline Men & 71.0 & 28.2 & 34.5 & 79.8 & 39.1 & 47.8 & 75.8 & 32.8 & 40.5 \\
\hline Women & 69.3 & 24.7 & 39.4 & 65.6 & 25.0 & 43.7 & 67.3 & 24.8 & 41.4 \\
\hline \multicolumn{10}{|l|}{ Education } \\
\hline High & 73.9 & 30.1 & 43.9 & 75.2 & 40.1 & 55.3 & 74.6 & 33.9 & 48.8 \\
\hline Mid & 67.1 & 27.9 & 34.8 & 72.2 & 37.8 & 48.3 & 69.5 & 31.0 & 39.4 \\
\hline Low & 57.3 & 21.7 & 26.7 & 59.0 & 26.6 & 34.4 & 58.4 & 24.1 & 30.7 \\
\hline \multicolumn{10}{|c|}{ Social Class } \\
\hline I & 85.3 & 34.0 & 46.7 & 82.0 & 50.9 & 64.2 & 83.2 & 40.1 & 55.0 \\
\hline II & 76.6 & 36.2 & 49.2 & 72.7 & 40.8 & 54.7 & 74.5 & 38.2 & 51.8 \\
\hline IIIN & 71.1 & 27.6 & 37.0 & 80.3 & 31.7 & 47.7 & 76.0 & 29.2 & 41.6 \\
\hline IIIM & 63.3 & 21.4 & 25.3 & 56.5 & 28.4 & 32.0 & 59.5 & 24.5 & 28.4 \\
\hline IV & 52.9 & 14.0 & 23.1 & 52.9 & 27.9 & 35.8 & 52.9 & 20.0 & 29.0 \\
\hline $\mathrm{V}$ & 41.4 & 6.3 & 16.3 & 44.7 & 11.9 & 24.2 & 43.3 & 8.9 & 20.3 \\
\hline
\end{tabular}

Note: Social Class groups based on occupation: Group I = Professional; Group II = Intermediate; Group IIIN = Skilled non-manual; Group IIIM = Skilled manual; Group IV = Semi-skilled manual; Group V = Unskilled manual. Total sample size = 5,030.

Source: Authors' calculations using data from the BHPS 2001. 
Table 2

Characteristics of members of DB pension schemes, by sex and sector

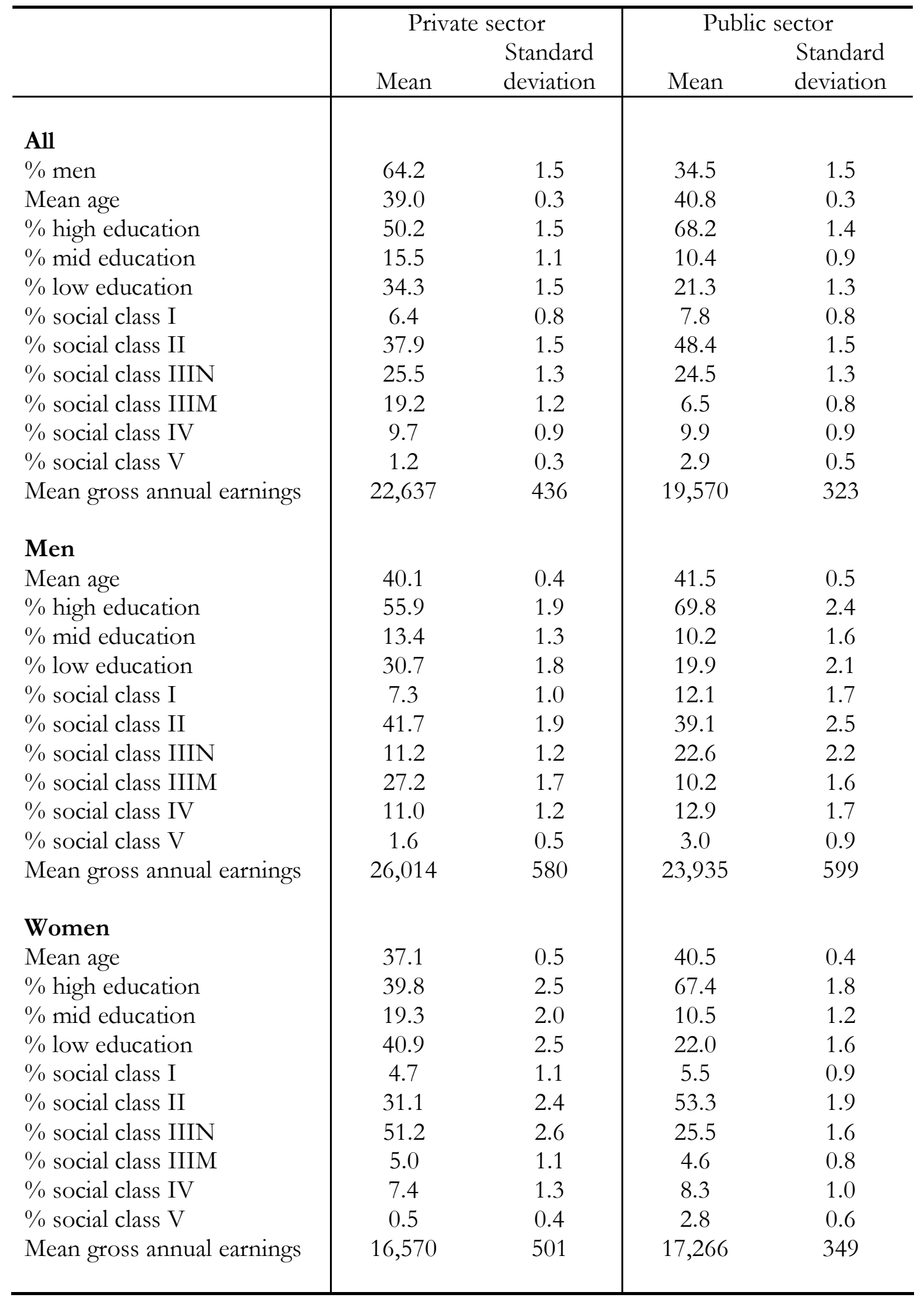

Note: Social Class groups based on occupation: Group I = Professional; Group II = Intermediate; Group IIIN = Skilled non-manual; Group IIIM = Skilled manual; Group IV = Semi-skilled manual; Group V = Unskilled manual. Total sample size = 2,134.

Source: Authors' calculations using data from the BHPS 2001. 
Table 3

Median estimated one-period accruals among members of DB pension schemes,

by sector and characteristic

\begin{tabular}{|c|c|c|c|c|c|c|}
\hline & \multicolumn{2}{|c|}{$\begin{array}{c}\text { Private sector } \\
\% \text { of }\end{array}$} & \multicolumn{2}{|c|}{$\begin{array}{c}\text { Public sector } \\
\% \text { of }\end{array}$} & \multicolumn{2}{|c|}{ Difference } \\
\hline All & 3,562 & 20.1 & 4,263 & 24.8 & 19.7 & +4.7 \\
\hline Men & & & & & & \\
\hline All & 4,008 & 19.4 & 4,938 & 24.1 & 23.2 & +4.7 \\
\hline High education & 5,139 & 20.6 & 5,764 & 25.7 & 12.2 & +5.1 \\
\hline Mid education & 3,569 & 18.5 & 4,490 & 24.0 & 25.8 & +5.5 \\
\hline Low education & 3,093 & 18.3 & 3,021 & 19.2 & -2.3 & +0.9 \\
\hline Social class I & 5,912 & 21.8 & 6,179 & 26.5 & 4.5 & +4.7 \\
\hline Social class II & 5,615 & 20.8 & 6,222 & 25.7 & 10.8 & +4.9 \\
\hline Social class IIIN & 3,179 & 19.5 & 5,367 & 25.7 & 68.8 & +6.3 \\
\hline Social class IIIM & 3,468 & 18.5 & 3,793 & 23.2 & 9.4 & +4.8 \\
\hline Social class IV & 2,514 & 16.9 & 3,026 & 20.4 & 20.4 & +3.6 \\
\hline Social class V & $\mathrm{n} / \mathrm{a}$ & $\mathrm{n} / \mathrm{a}$ & $\mathrm{n} / \mathrm{a}$ & $\mathrm{n} / \mathrm{a}$ & $\mathrm{n} / \mathrm{a}$ & $\mathrm{n} / \mathrm{a}$ \\
\hline Women & & & & & & \\
\hline All & 2,868 & 21.1 & 3,937 & 25.1 & 37.3 & +4.0 \\
\hline High education & 3,942 & 22.2 & 4,874 & 26.4 & 23.6 & +4.2 \\
\hline Mid education & 2,961 & 21.1 & 2,909 & 24.4 & -1.8 & +3.3 \\
\hline Low education & 2,380 & 20.7 & 2,156 & 22.3 & -9.4 & +1.6 \\
\hline Social class I & $\mathrm{n} / \mathrm{a}$ & $\mathrm{n} / \mathrm{a}$ & 5,932 & 25.9 & $\mathrm{n} / \mathrm{a}$ & $\mathrm{n} / \mathrm{a}$ \\
\hline Social class II & 4,624 & 22.0 & 4,929 & 26.3 & 6.6 & +4.3 \\
\hline Social class IIIN & 2,531 & 21.1 & 2,843 & 24.5 & 12.3 & +3.4 \\
\hline Social class IIIM & $\mathrm{n} / \mathrm{a}$ & $\mathrm{n} / \mathrm{a}$ & 2,410 & 23.9 & $\mathrm{n} / \mathrm{a}$ & $\mathrm{n} / \mathrm{a}$ \\
\hline Social class IV & $\mathrm{n} / \mathrm{a}$ & $\mathrm{n} / \mathrm{a}$ & 1,814 & 22.8 & $\mathrm{n} / \mathrm{a}$ & $\mathrm{n} / \mathrm{a}$ \\
\hline Social class V & $\mathrm{n} / \mathrm{a}$ & $\mathrm{n} / \mathrm{a}$ & $\mathrm{n} / \mathrm{a}$ & $\mathrm{n} / \mathrm{a}$ & $\mathrm{n} / \mathrm{a}$ & $\mathrm{n} / \mathrm{a}$ \\
\hline
\end{tabular}

Note: Social Class groups based on occupation: Group I = Professional; Group II = Intermediate; Group IIIN = Skilled non-manual; Group IIIM = Skilled manual; Group IV = Semi-skilled manual; Group V = Unskilled manual. Figures based on sample sizes of less than 30 not reported, those in italics signify sample size between 30 and 50.

Source: Authors' calculations using data from the BHPS (2001) and the LFS (1994 to 2006). 
Table 4

Composition of differences in estimated one-period accrual between public and private sector DB schemes

\begin{tabular}{|c|c|c|}
\hline & \multicolumn{2}{|c|}{ Median accrual } \\
\hline & $£$ & $\%$ of earnings \\
\hline All (sample size $=1,074)$ & & \\
\hline Public sector rules and earnings profiles & 4,263 & 24.8 \\
\hline Private sector rules and public sector earnings profiles & 3,638 & 21.6 \\
\hline Private sector rules and earnings profiles & 3,232 & 21.1 \\
\hline Those aged under 40 (sample size $=488)$ & & \\
\hline Public sector rules and earnings profiles & 4,463 & 25.7 \\
\hline Private sector rules and public sector earnings profiles & 3,859 & 22.1 \\
\hline Private sector rules and earnings profiles & 4,039 & 23.3 \\
\hline Those aged 40 and over $($ sample size $=586)$ & & \\
\hline Public sector rules and earnings profiles & 4,049 & 24.2 \\
\hline Private sector rules and public sector earnings profiles & 3,492 & 21.3 \\
\hline Private sector rules and earnings profiles & 2,468 & 18.1 \\
\hline
\end{tabular}

Source: Authors’ calculations using data from the BHPS (2001) and the LFS (1994 to 2006). 
Figure 1

Numbers of members of contracted out defined benefit pension schemes by sector, 1978-79 to 2003-04 (thousands).

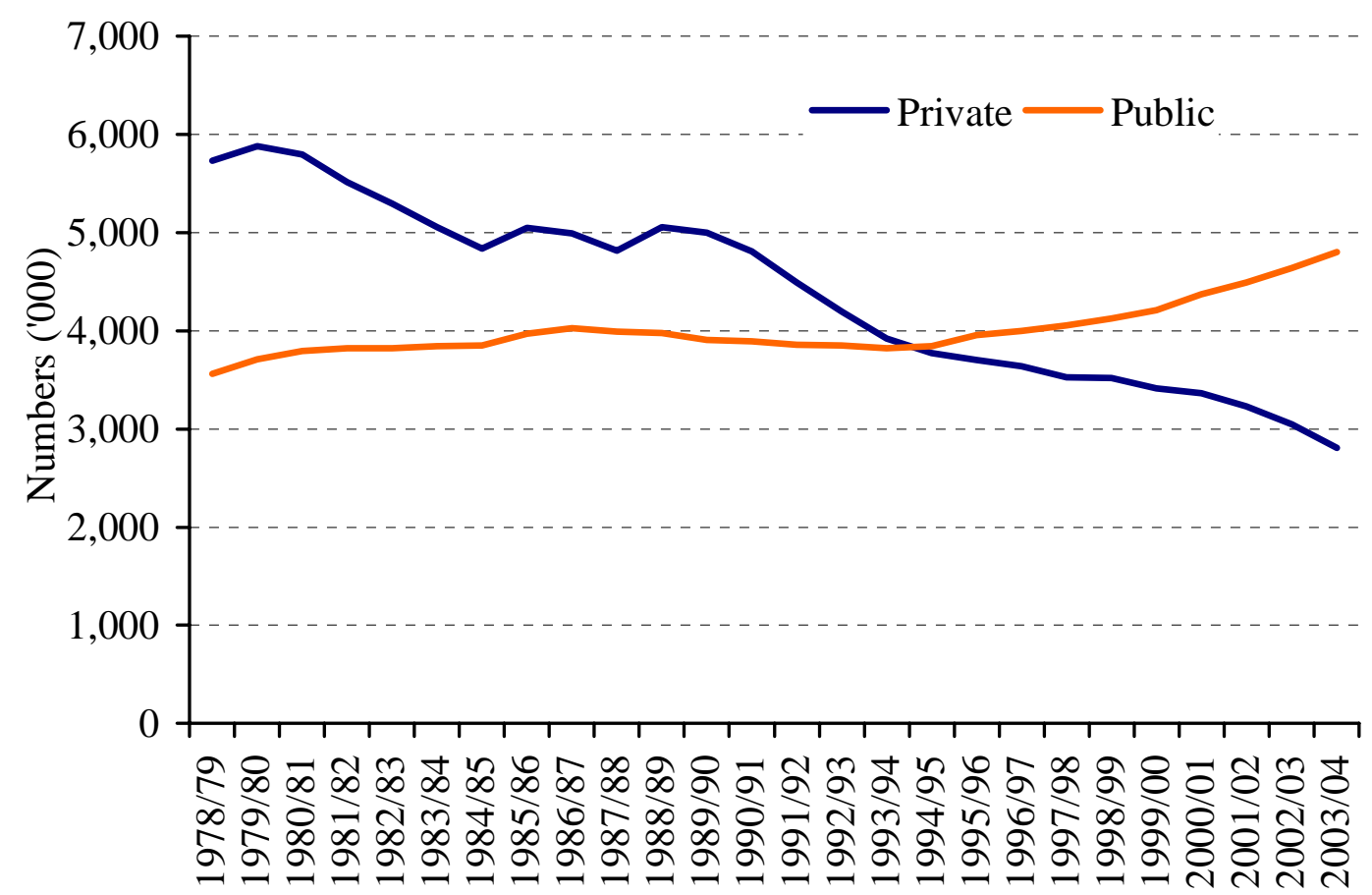

Financial year

Source: DWP Second Tier Pension Statistics.

http://www.dwp.gov.uk/asd/asd1/tabtools/stpp_summary.xls 
Figure 2

Median age-earnings profiles, public and private sector by educational group
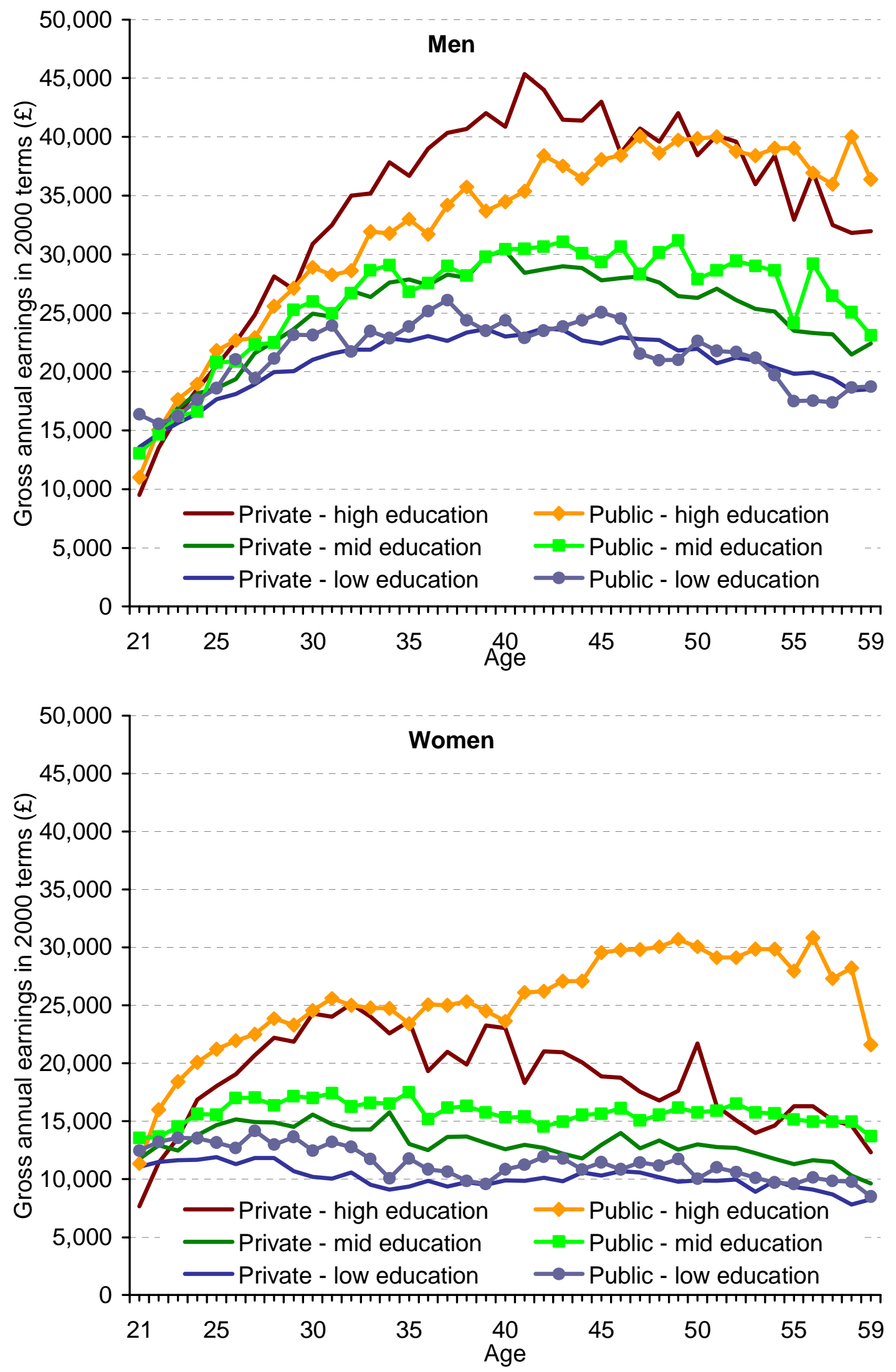

Note: Profiles exclude sector specific earnings growth.

Source: Authors' calculations using data from the LFS (1994 to 2006). 
Figure 3

Cumulative distribution of simulated one-period defined benefit pension accumulation as a percentage of current pay, by sector, those aged between 16 and the State Pension Age in 2001

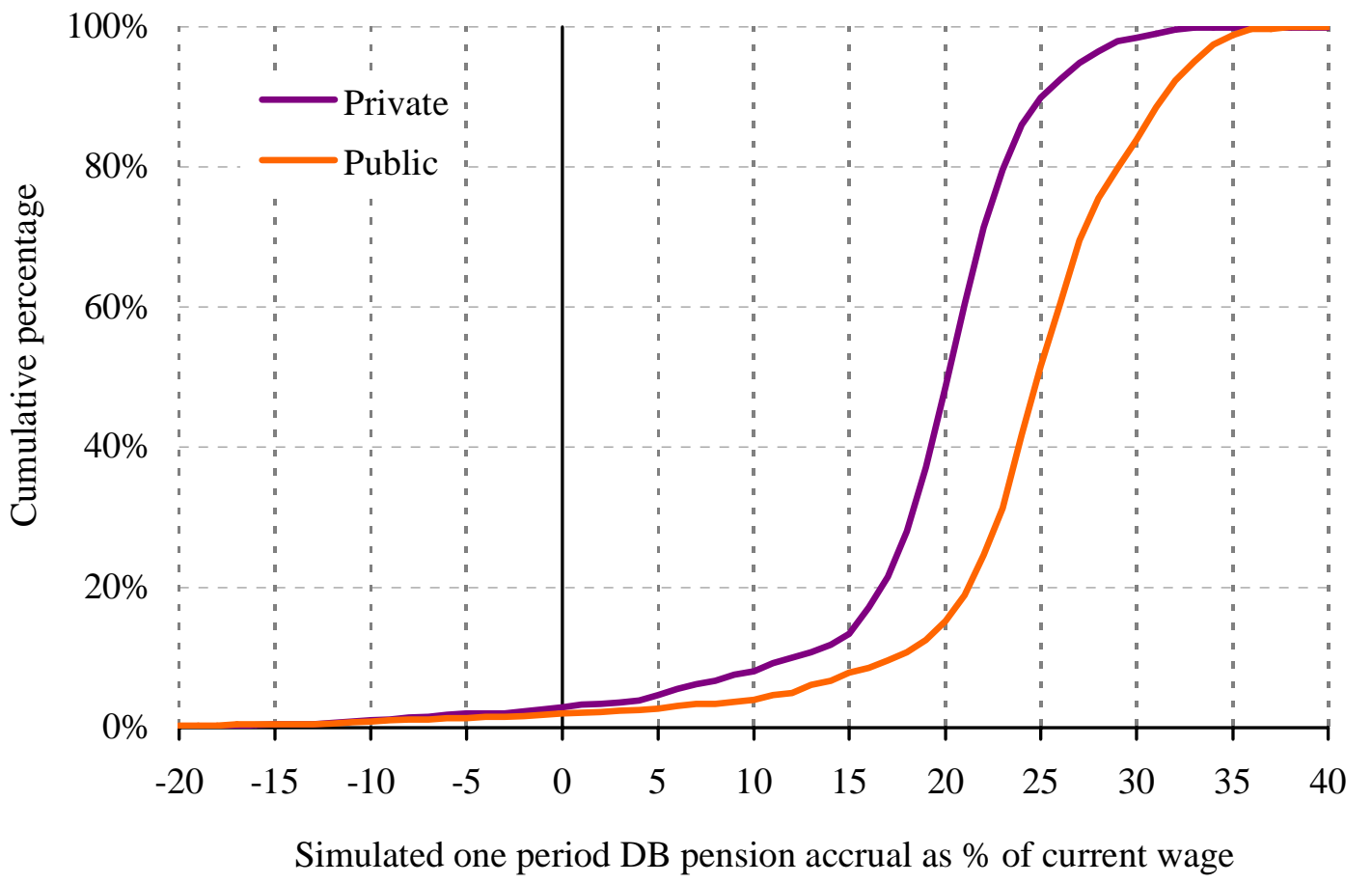

Note: Sample size 2,134 comprising 1,060 members of private sector schemes and 1,074 members of public sector schemes.

Source: Authors' calculations using data from the BHPS (2001) and the LFS (1994 to 2006). 